\title{
EFFECT OF FRAGMENTATION AND ANTHROPOGENIC DISTURBANCES ON FLORISTIC COMPOSITION AND STRUCTURE OF SUBTROPICAL BROAD LEAVED HUMID FOREST IN MEGHALAYA, NORTHEAST INDIA
}

\author{
PAO, N. T. ${ }^{1}$ - UPADHAYA, K. $^{2^{*}}$ \\ ${ }^{1}$ Department of Environmental Studies, School of Human and Environmental Sciences North- \\ Eastern Hill University, Shillong 793 022, India \\ (phone: +91-9-402-008-491; e-mail: atrune@gmail.com) \\ ${ }^{2}$ Department of Basic Sciences and Social Sciences, School of Technology, North-Eastern Hill \\ University; Shillong 793022 \\ (phone +91-9-436-119-857) \\ * Corresponding author \\ e-mail: upkri@yahoo.com
}

(Received 26 $6^{\text {th }}$ Mar 2017; accepted 21 ${ }^{\text {st }}$ Jul 2017)

\begin{abstract}
The subtropical broadleaved humid forest of Meghalaya, northeast India are characterised by small remnant patches. The major threats to the existing patches are anthropogenic activities such as encroachment of forest area, mining, extraction of forest resources, grazing and forest fire. The present study was carried out at Jarain and adjoining areas of Jaintia Hills in Meghalaya, northeast India to identify the current human disturbances and assess the floristic composition and structure of subtropical broad leaved forest along a fragment size gradient. Floristic sampling was carried out by laying 24 plots $(20 \mathrm{mx} 100 \mathrm{~m})$ across 10 forest fragments covering a sampled area of 4.8 ha. A total of 160 woody species $(\geq 5 \mathrm{~cm}$ dbh) belonging to 105 genera and 54 families were enumerated from all the studied fragments. The species richness was 69 in Small, 75 in Medium, 76 in Very Large (VL) and 77 in Large (L) fragment classes. In this study, Pearson's correlation analysis was performed to analyse the relationship between area, disturbance and phytosociological attributes. The results showed that the stand density increased $(\mathrm{r}=$ $0.71, p=0.01)$, while basal area decreased with disturbance $(r=-0.74, p=0.01)$. The density was high in 5$15 \mathrm{~cm}$ dbh class that gradually declined with the increase in diameter. The basal area was high in $>66 \mathrm{~cm}$ dbh class in Very Large fragments whereas in small patches, the values were higher in $16-25 \mathrm{~cm}$ dbh classes. The forests fragments under study also have a number of rare, endemic and threatened species. Therefore, it is suggested that the entire landscape be brought under the protected area network due to high species diversity.
\end{abstract}

Keywords: area, conservation, species diversity, density, Jarain

\section{Introduction}

Fragmentation of large continuous tracts of forest into smaller patches leads to biodiversity loss, population shift, collapse of community assembly and ecosystem integrity (Mikkelson, 1993). The species richness in the fragments are determined by a number of attributes such as geographical location, topography, shape, management regimes, landuse history, internal disturbances (Ochoa- Guano et al., 2004) and the rate of colonisation and extinction of species over a period of time (Vellend et al., 2006). Though time scale is an indispensible variable in fragmentation studies particularly on plant community which are long lived and their response is slow, the debt of extinction due to fragmentation is inescapable (Vellend et al., 2006). There are two views regarding the effect of fragment size on biodiversity conservation. According to one of 
the views (the theory of island biogeography), fragments of larger area are supposedly assumed to harbour more species than the smaller fragments (Mac Arthur and Wilson, 1967). Larger fragments provide opportunity for establishment of varied microhabitats, space and resources to support more species and individuals (Schoener, 2010). Contrary to this, there are studies that have established that network of several small fragments have the potential of conserving biodiversity of a region (Toledo-Aceves et al., 2014; Ziter et al., 2013). In smaller fragments there is a high species turnover (ArroyoRodriguez et al. 2008). The consequence of fragmentation on species diversity may not be a linear species-area curve but are reflected through its response to edge effect which can cause cascading effects on the ecosystem. Tree species may be impoverished due to the loss of disturbance sensitive species in the fragments (Tabarrelli et al., 2004).

The larger fragments have more interior and are expected to support more of shade tolerant species (Benchimol and Peres, 2015). Species are susceptible to edge effect due to alteration in physical processes such as increase insolation, windthrow (Murcia, 1995; Laurance et al., 2000) and invasion by early successional species (Tabarelli et al., 2004). Gradual development of edge, affect the plant community since the ecological traits of the species may not be compatible with the conditions prevalent in the remnant habitat. The proportions of evergreen species in the edges are often replaced by deciduous elements associated with traits more adaptable to disturbance by shedding off their leaves to reduce water loss (Orihuela et al., 2015). Creation of edge may favour establishment of lianas (Laurance et al., 1998; Chettri, 2010) and light tolerant species (Ochoa-Gaona et al., 2004). However, epiphytes and herbaceous community may be threatened due to death of old growth trees that serves as host for the former and filter excess solar radiation to the herbaceous community (Hofmeister et al., 2013; Kolk and Naaf, 2015). Further, the invasion by light demanding species may pose competition with native old growth species that may alter the composition and structure of the community affecting ecosystem functions (Zhu et al., 2004).

Fragmented patches are more exposed to anthropogenic disturbances and small patches are highly susceptible to resource extraction that could further degrade the remnants (Cayuela et al., 2006). Although large reserves are usually preferred over smaller ones for conservation purpose, the effectiveness of forest patches to retain habitat core condition (Hofmeister et al., 2013), large subsets of species diversity and forest structure is still controversial (Lindenmayer et al., 2008; Gardner et al., 2009). There are studies that have established that species diversity increases with fragment size (Turner, 1996; Laurance et al., 2002). Contrary to this, species diversity has been observed to be independent of fragment sizes (Arroyo-Rodriguez et al., 2008; Hernandez-Reudas et al., 2014). Remnant patches can be of special interest irrespective of size because they may represent some of the only habitat left for certain species which are susceptible to disturbances particularly fragmentation. They may also have similar species diversity, complimentary to larger habitat necessary for biodiversity conservation and ecosystem services (Godefroid and Koedem, 2003). The consequence of fragmentation is of serious concern especially for species that are endemic, threatened or having ecological and economic interest.

The state of Meghalaya in northeast India is a part of the Indo-Burma hotspot (Mittermeier et al., 2004) and is rich in biological wealth and endemism (Upadhaya et al., 2012). The state supports various forest types ranging from tropical- evergreen, semi evergreen to subtropical- broad leaved and -pine. The subtropical broadleaved humid forest found in higher altitudes $(\geq 900 \mathrm{~m}$ asl) of the state have been recognised 
for their high species diversity and endemism (Upadhaya et al., 2003; Pandey et al., 2005; Jamir et al., 2006; Upadhaya, 2015). However, they occur in the form of highly fragmented patches and are poorly represented in the protected area network of the state (Upadhaya et al., 2013). The remnant subtropical forests are exposed to various kinds of disturbances and most of them have been converted to Pine (Pinus kesiya) dominated forest (Sarma, 2005). Other human activities such as overexploitation, deforestation, shifting cultivation, mining and urbanization have further contributed to the loss of subtropical broad leaved forest. Therefore, the present study was carried out at Jarain and adjoining areas of Jaintia Hills in Meghalaya, northeast India to:

- identify the current human disturbances operating in the remnant patches

- assess the floristic composition and structure of the forests along a fragment size gradient.

\section{Materials and Methods}

\section{Study Sites}

For the present study, forest fragments of different sizes ranging from 3.79 to 105 ha

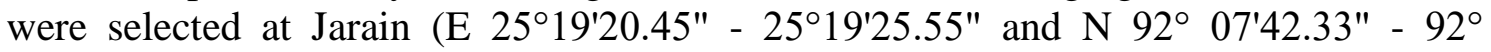
09'23.09", altitudinal range 1000m-1200msl), in Jaintia Hills of Meghalaya, northeast India. These patches were located within $5 \mathrm{~km}$ radius and represents similar climatic and edaphic conditions (Figure 1 and 2). The vegetation in the study area represents subtropical broad leaved humid forest (Champion and Seth, 1968). It is dense with short stature and the height of the tree rarely exceeds $18 \mathrm{~m}$. The trees are distributed in three distinct strata and species like Castanopsis spp., Daphniphyllum himalayenses, Eleocarpus lanceifolius, Engelhardtia spicata, Lithocarpus fenestratus, Magnolia insignis, Myrica esculenta, Persea odoratissima, Quercus semiserrata, Sarcosperma griffithii and Schima wallichii usually forms the canopy layer. The species such as Litsea elongata, Rhus acuminata, Syzygium tetragonum, Helecia nilagirica, Ligustrum robustrum and Lithocarpus dealbatus forms the subcanopy layer. The undercanopy layer is dominated by large shrub or small trees such as Camellia caduca, C. caudata, Daphne involucrata, Erythroxylon kunthianum, Eurya acuminata, Myrsine semiserrata, Symplocos spicata, Syzygium cuminii etc. (Jamir et al., 2006; Pao et al., 2016).

The climate of the area is monsoonic with a distinct wet and dry period. The wet period extends from April to October during which more than $80 \%$ of the total rainfall occurs. The dry period extends from November to March with a rainfall of $<20 \mathrm{~mm}$ and are characterized by low temperature $\left(8^{\circ} \mathrm{C}\right)$. In spring (April-May), the temperature starts to rise and there are few showers of rain as shown in Figure 3 (Pao et al., 2016).

The Jaintia Hills is a continuation of the Meghalaya Plateau formed from the remnants of Pre-cambrian Indian peninsular shield. The rocks are mostly of Precambrian origin with gneissic composition such as granites, schist, amphibolits and calc-silicate (Central Groundwater Board, 2013). Soil texture of the studied sites varied from loamy sand to sandy. Bulk density ranged from 0.95 to $1.26 \mathrm{~g} \mathrm{~cm}^{-3}$ whereas, the porosity varied from 46.53 to $64.02 \%$. The soil was acidic in nature (pH 5.4). 


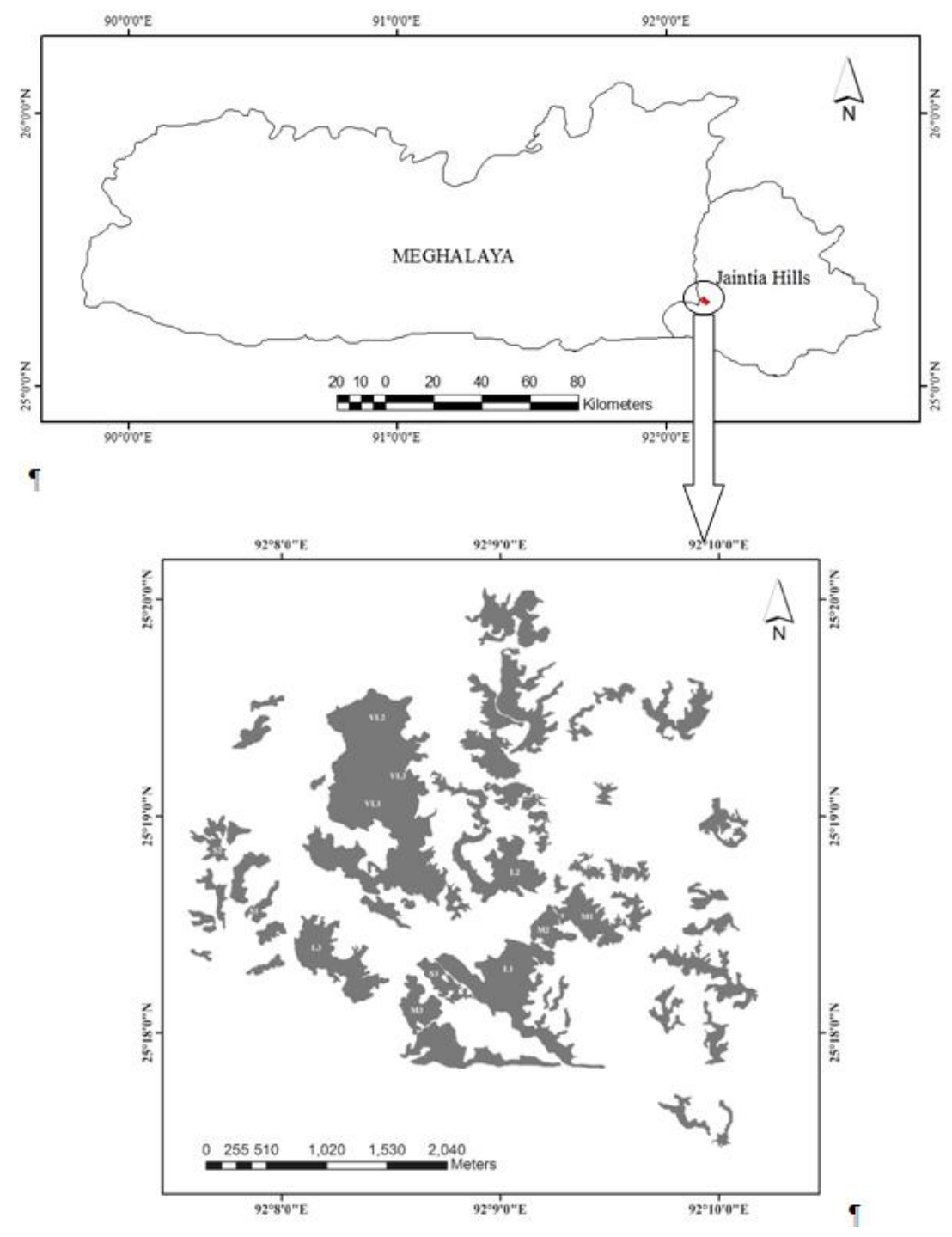

Figure 1. Map showing study area in Jaintia hills of Meghalaya, northeast India
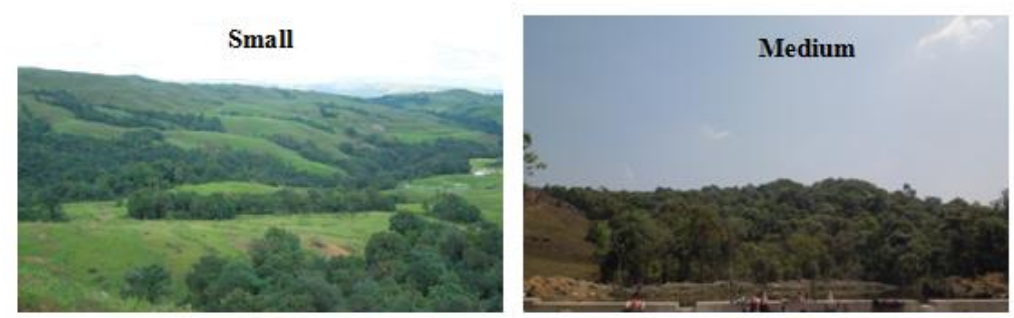

Large

Very Large
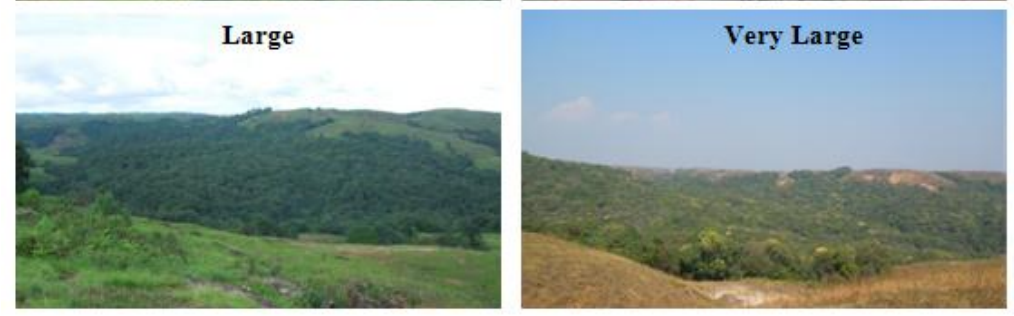

Figure 2. View of the landscape and some of the fragments in Jarain area of Jaintia Hills, Meghalaya, northeast India

APPLIED ECOLOGY AND ENVIRONMENTAL RESEARCH 15(4):385-407. http://www.aloki.hu • ISSN 15891623 (Print) • ISSN 17850037 (Online) DOI: http://dx.doi.org/10.15666/aeer/1504_385407 (c) 2017, ALÖKI Kft., Budapest, Hungary 


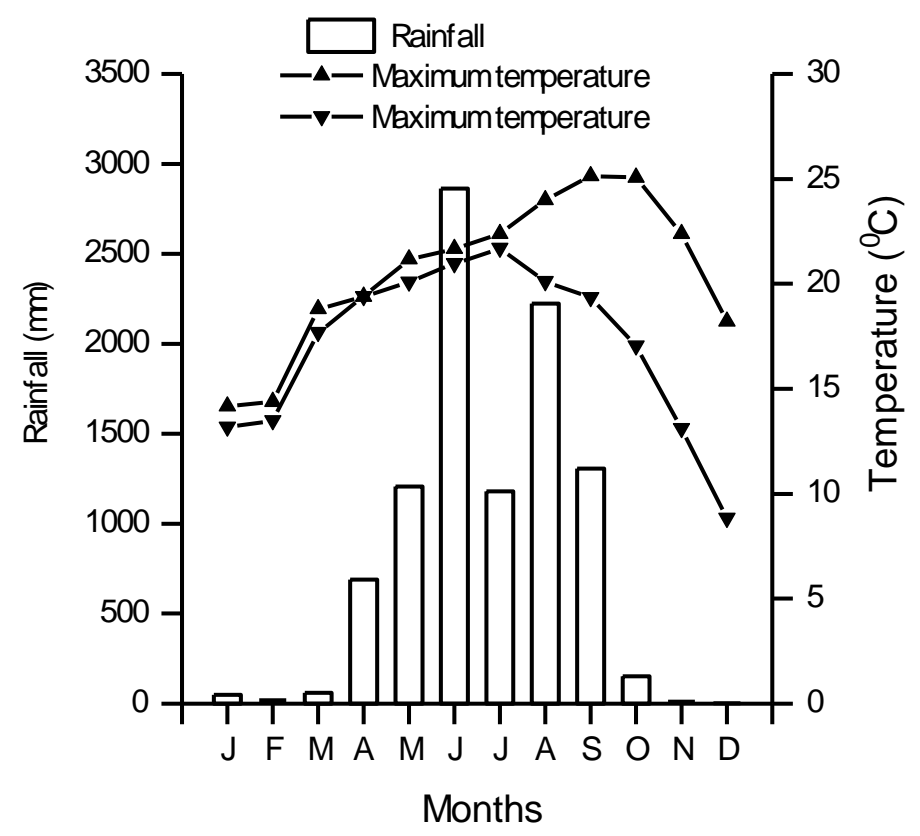

Figure 3. Mean maximum and minimum temperatures and precipitation at Jowai for the year 2015 (Source:http://www.megagriculture.gov.in)

\section{Sampling Design}

The 10 fragments of different sizes selected for the study were arbitrarily classified into four classes viz. Small ( $<4$ ha), Medium ( $>5$ and $<15$ ha), Large ( $>15$ and $<50$ ha) and Very Large (105 ha) to study the phytosociological attributes along a fragment size gradient. Three replicate fragments were maintained for each fragment class. However, in the case of the Very Large, three replicated plots were maintained from a single large fragment due to lack of large continuous forests in the study area (Santos et al., 2007). These replicated sites were abbreviated as S (S1, S2, S3), M (M1, M2, M3), L (L1, L2, L3) and VL (VL1, VL2, VL3) respectively (Table 1). All the fragments were once a part of the same forest.

The disturbance index for each site was assessed following Mir et al. (2016). A score of 0 to 10 was assigned to each anthropogenic factor viz., extraction of -timber, -fuel wood, encroachment upon forest land for settlement, agriculture, mining and quarrying; road construction, NTFP's collection, construction of ponds, grazing and fire. A score of 0 was considered to be negligible, 1 as low, 5 as intermediate and 10 as high. The forest having all the disturbances at the highest intensity would have a total score of 110.

For vegetation sampling extensive field survey was carried out from 2013-2015. To capture the heterogeneity of structure and composition of the plant community, in each fragment, two transects of $20 \mathrm{mx} 100 \mathrm{~m}$ were laid, one along the edge of the forest while the other was laid at a distance of 50m from the first tree on the edge (Page et al., 2009). Each transect was further divided into 20 quadrats of $10 \mathrm{mx} 10 \mathrm{~m}$ size for inventorization of all woody species having a diameter at breast height (dbh) of $\geq 5 \mathrm{~cm}$. The specimens were collected and identified using regional floras and the Herbaria at Botanical Survey of India, Eastern Regional Circle, Shillong. The nomenclature of the species follows the regional flora. 
Table 1. Neighbouring landscape unit and the current human disturbances in the study area

\begin{tabular}{|c|c|c|c|c|c|c|c|}
\hline \multirow{2}{*}{$\begin{array}{l}\text { Fragment } \\
\text { Class }\end{array}$} & \multirow{2}{*}{ Site } & \multirow{2}{*}{$\begin{array}{l}\text { Area } \\
\text { (ha) }\end{array}$} & \multicolumn{2}{|c|}{ GPS coordinates } & \multirow{2}{*}{ Neighbouring landscape unit } & \multirow{2}{*}{ Current human disturbances } & \multirow{2}{*}{ Disturbance } \\
\hline & & & Longitutdes & Latitudes & & & \\
\hline \multirow{3}{*}{ Small } & S1 & 3.79 & N 2519'25.55" & E $92^{\circ} 07^{\prime} 54.67^{\prime \prime}$ & $\begin{array}{l}\text { Streams, road, grassland, } \\
\text { reforested areas }\end{array}$ & $\begin{array}{l}\text { Extraction of timber and fuel wood, fire, browsing, construction of - } \\
\text { road, -pond, NTFP extraction }\end{array}$ & 51 \\
\hline & S3 & 4.99 & N $25^{\circ} 18^{\prime} 15.63^{\prime \prime}$ & E $92^{\circ} 08^{\prime} 43.60^{\prime \prime}$ & $\begin{array}{l}\text { Human settlement, road, } \\
\text { grassland }\end{array}$ & $\begin{array}{l}\text { Extraction of timber and fuel wood, fire, browsing, construction of } \\
\text { road, encroachment due to human settlement, NTFP extraction }\end{array}$ & 47 \\
\hline & M1 & 13.2 & N $25^{\circ} 18^{\prime} 37.22^{\prime \prime}$ & E $92^{\circ} 09^{\prime} 23.09^{\prime \prime}$ & Pond, road, grassland & $\begin{array}{l}\text { Extraction of timber and fuel wood, construction of - road, -pond, } \\
\text { NTFP extraction }\end{array}$ & 40 \\
\hline \multirow[t]{2}{*}{ Medium } & M2 & 6.23 & N $25^{\circ} 18^{\prime} 29.55^{\prime \prime}$ & E $92^{\circ} 09^{\prime} 14.22^{\prime \prime}$ & $\begin{array}{l}\text { Stream, grassland, road, stone } \\
\text { quarry, crematory ground }\end{array}$ & $\begin{array}{l}\text { Extraction of timber and fuel wood, browsing, construction of road, } \\
\text { encroachment due to quarrying, NTFP extraction }\end{array}$ & 27 \\
\hline & M3 & 8.72 & N $25^{\circ} 18^{\prime} 10.70^{\prime \prime}$ & E $92^{\circ} 08^{\prime} 37.97 "$ & $\begin{array}{l}\text { Human settlement, grassland, } \\
\text { coal mine, settled agriculture, } \\
\text { jhum plots }\end{array}$ & $\begin{array}{l}\text { Extraction of timber and fuel wood, browsing, construction of road, } \\
\text { encroachment due to -agriculture, -quarrying, -human settlement, } \\
\text { NTFP extraction }\end{array}$ & 70 \\
\hline \multirow{3}{*}{ Large } & L1 & 28.7 & $\mathrm{~N} 25^{\circ} 18^{\prime} 08.15^{\prime \prime}$ & E $92^{\circ} 08^{\prime} 56.48^{\prime \prime}$ & $\begin{array}{l}\text { Pond, road, stream, human } \\
\text { settlement, cattle shed, settled } \\
\text { agriculture }\end{array}$ & $\begin{array}{l}\text { Extraction of timber and fuel wood, browsing, encroachment due to to } \\
\text {-agriculture, -quarrying, -human settlement, NTFP extraction }\end{array}$ & 61 \\
\hline & L2 & 19.6 & N 2518'40.39" & E $92^{\circ} 09^{\prime} 23.09^{\prime \prime}$ & $\begin{array}{l}\text { Stream, human settlement, cattle } \\
\text { shed, settled agriculture, ponds, }\end{array}$ & $\begin{array}{l}\text { Extraction of timber, browsing, construction of pond, NTFP } \\
\text { extraction }\end{array}$ & 17 \\
\hline & L3 & 21.02 & N $25^{\circ} 18^{\prime} 10.23^{\prime \prime}$ & E $92^{\circ} 08^{\prime} 25.19^{\prime \prime}$ & $\begin{array}{l}\text { Ponds, road, coal mines, stone } \\
\text { quarry, human settlement, } \\
\text { farming }\end{array}$ & $\begin{array}{l}\text { Extraction of timber and fuel wood, fire, browsing, construction of - } \\
\text { road, -pond, encroachment due to -agriculture, -quarrying, -human } \\
\text { settlement, NTFP extraction }\end{array}$ & 39 \\
\hline \multirow{3}{*}{ Very Large } & VL1 & 105 & N $25^{\circ} 19^{\prime} 08.78^{\prime \prime}$ & E $92^{\circ} 08^{\prime} 39.41 "$ & $\begin{array}{l}\text { Stream, human settlement, } \\
\text { grassland, coal mines, settled } \\
\text { agriculture, jhum plots }\end{array}$ & $\begin{array}{l}\text { Extraction of timber and fuel wood, browsing, encroachment due to } \\
\text { mining, NTFP extraction }\end{array}$ & 14 \\
\hline & VL2 & 105 & N 2519'20.45" & Е $92^{\circ} 08^{\prime} 17.66^{\prime \prime}$ & $\begin{array}{l}\text { Stream, coal mine, cattle raring, } \\
\text { grassland, agriculture plots }\end{array}$ & $\begin{array}{l}\text { Extraction of timber and fuel wood, fire, browsing, encroachment due } \\
\text { to mining, NTFP extraction, }\end{array}$ & 19 \\
\hline & VL3 & 105 & N $25^{\circ} 18^{\prime} 56.73^{\prime \prime}$ & Е $92^{\circ} 08^{\prime} 19.30^{\prime \prime}$ & $\begin{array}{l}\text { Crematory ground, coal mines, } \\
\text { quarry, grassland, roads }\end{array}$ & $\begin{array}{l}\text { Extraction of timber and fuel wood, browsing, encroachment due to - } \\
\text { agriculture, -mining, NTFP extraction }\end{array}$ & 36 \\
\hline
\end{tabular}




\section{Data Analysis}

The vegetation data from the two transect for each sites were pooled together. Community parameters such as frequency, density, basal area and importance value index (IVI) were computed following Misra (1968) and Mueller-Dombois and Ellenberg (1974). Various diversity indices such as Shannon Wiener, Simpson and Pielou were calculated following Magurran (1998). Sorensen's index of similarity (Sorensen, 1948) was used for comparing the floristic similarity between the fragments. A check list of rare, endemic and threatened species occurring in the study area was prepared based on published literature (Pandey et al., 2005; Upadhaya et al., 2013) and the recent IUCN Red List (IUCN, 2016).

Pearson correlations analysis was performed to examine the effect of fragment size and anthropogenic disturbances on species richness, density, basal area and various diversity indices. The software SPSS statistical package (Version 20) was used for statistical analysis.

\section{Results}

\section{Site Characteristics and Disturbances}

The fragmented patches under study were scattered amidst degraded grassland and human habitation. The major threats to the existing remnant patches are anthropogenic disturbances. Encroachment of forest land for agriculture, settlement, mining of coal, construction of ponds around streams and sand mining are common sight around most of the patches. Timber and non-timber forest product extraction, browsing, rampant fire during winter are also threatening the very existence of these remnant patches (Table 1). The number of cut stumps was high in S2 (105 stems) followed by M3 (94) and L1 (90) as shown in Table 2. Forest fragments M3, L1, S1 and S3 were highly disturbed whereas, S2, M1, M2, L3 and VL3 were mildly disturbed. The remaining three forest fragments L2, VL1 and VL2 were least disturbed. The patches close to human habitation were more disturbed (Table 1).

\section{Floristic Composition and Diversity}

A total of 160 woody species ( $\geq 5 \mathrm{~cm} \mathrm{dbh}$ ) belonging to 105 genera and 54 families were enumerated from all the studied fragments. The average species richness per patch was $75 \pm 2$. The species richness in the fragments ranged from 60 species in $\mathrm{S} 2$ to 83 in M1, L2 and VL1 fragments. The mean number of species was 69 species in Small Fragment class(S), 75 in Medium (M), 76 in Very Large (VL) and 77 in Large (L) classes (Table 2). The species richness did not increase with the increase in patch area $(\mathrm{r}$ $=0.16, \mathrm{p}=0.61)$. The studied fragments had a number of rare, endemic and threatened species (Appendix 1). Overall, the family Rubiaceae had the highest number of genera (8) followed by Lauraceae (7) and Rutaceae (6). In terms of species richness, Fagaceae was the dominant family with 17 species, followed by Rubiaceae (13) and Lauraceae (11).

Diversity indices varied among different fragment classes. The mean Shannon Wiener's diversity index (H') values ranged from 3.54 in Small to 3.76 in Medium fragment, while Large and Very Large showed a value of 3.56 and 3.64 respectively. Based on the $\mathrm{H}^{\prime}$ values the fragment classes can be arranged in the order of 


$$
-392 \text { - }
$$

$\mathrm{M}>\mathrm{VL}>\mathrm{L}>\mathrm{S}$. The Simpson's dominance index (D) showed a reverse trend to that of H'values. Based on the dominance index the fragments can be arranged in the order of $\mathrm{S}=\mathrm{L}>\mathrm{VL}>\mathrm{M}$. The values ranged from 0.03 to 0.05 . Pielou's eveness index $(\mathrm{J})$ ranged from 0.82 to 0.87 in all the fragments (Table 2).

Table 2. Species richness, density, basal area and diversity indices (per 0.4 ha) in different fragments

\begin{tabular}{c|c|c|c|c|c|c|c}
\hline $\begin{array}{c}\text { Fragment } \\
\text { Category }\end{array}$ & $\begin{array}{c}\text { Species } \\
\text { Richness }\end{array}$ & Density & $\begin{array}{c}\text { Basal } \\
\left.\text { Area } \mathbf{( m}^{2}\right)\end{array}$ & $\mathbf{H}^{\prime}$ & D & J & $\begin{array}{c}\text { No. of Cut } \\
\text { stumps }\end{array}$ \\
\hline S1 & 77 & 670 & 17.41 & 3.74 & 0.034 & 0.86 & 39 \\
S2 & 60 & 620 & 17.47 & 3.41 & 0.052 & 0.83 & 105 \\
S3 & 72 & 651 & 20.17 & 3.46 & 0.056 & 0.81 & 53 \\
Mean & $69 \pm 5$ & $647 \pm 15$ & $18.35 \pm 0.91$ & $3.54 \pm 0.1$ & $0.05 \pm 0.01$ & $0.83 \pm 0.01$ & 66 \\
M1 & 83 & 663 & 16.84 & 3.92 & 0.025 & 0.88 & 49 \\
M2 & 79 & 612 & 19.35 & 3.84 & 0.028 & 0.88 & 55 \\
M3 & 67 & 743 & 16.47 & 3.53 & 0.046 & 0.84 & 94 \\
Mean & $75 \pm 5$ & $673 \pm 38$ & $17.55 \pm 0.9$ & $3.76 \pm 0.1$ & $0.03 \pm 0.01$ & $0.87 \pm 0.02$ & 66 \\
L1 & 75 & 713 & 15.82 & 3.59 & 0.052 & 0.84 & 90 \\
L2 & 83 & 501 & 21.02 & 3.74 & 0.039 & 0.84 & 24 \\
L3 & 72 & 628 & 20.7 & 3.35 & 0.07 & 0.78 & 30 \\
Mean & $77 \pm 3$ & $614 \pm 62$ & $19.18 \pm 1.7$ & $3.56 \pm 0.1$ & $0.05 \pm 0.01$ & $0.82 \pm 0.02$ & 48 \\
VL1 & 83 & 690 & 19.95 & 3.86 & 0.029 & 0.87 & 10 \\
VL2 & 69 & 597 & 20.85 & 3.41 & 0.053 & 0.80 & 62 \\
VL3 & 76 & 626 & 21.68 & 3.66 & 0.041 & 0.84 & 22 \\
Mean & $76 \pm 4$ & $637 \pm 27$ & $20.83 \pm 0.5$ & $3.64 \pm 0.1$ & $0.04 \pm 0.01$ & $0.84 \pm 0.02$ & 31 \\
\hline
\end{tabular}

\section{Similarity}

The species composition of the fragments in the study sites showed high similarity index ranging from 52-77\% (Table 3). The similarity percentage between L1 and VL3 was highest (77\%) and the least between VL2, M2 and M3 (mean 52.5\%). The mean percentage of similarity among the fragment classes are $67 \%$ for Small, $63 \%$ for Medium, 69\% for Large and 65\% for Very Large respectively (Table 3).

Table 3. Sorensen's similarity index (\%) among the different fragments

\begin{tabular}{c|c|c|c|c|c|c|c|c|c|c|c|c}
\hline & S1 & S2 & S3 & M1 & M2 & M3 & L1 & L2 & L3 & VL1 & VL2 & VL3 \\
\hline S1 & 1 & & & & & & & & & & & \\
S2 & 66 & 1 & & & & & & & & & & \\
S3 & 67 & 68 & 1 & & & & & & & & & \\
M1 & 68 & 59 & 66 & 1 & & & & & & & & \\
M2 & 64 & 65 & 68 & 59 & 1 & & & & & & & \\
M3 & 68 & 60 & 69 & 66 & 63 & 1 & & & & & & \\
L1 & 67 & 71 & 68 & 61 & 66 & 68 & 1 & & & & & \\
L2 & 75 & 66 & 63 & 65 & 67 & 69 & 71 & 1 & & & & \\
L3 & 72 & 61 & 61 & 57 & 56 & 61 & 69 & 68 & 1 & & & \\
VL1 & 68 & 64 & 61 & 60 & 64 & 60 & 65 & 71 & 68 & 1 & & \\
VL2 & 67 & 57 & 61 & 58 & 52 & 53 & 60 & 58 & 62 & 67 & 1 & \\
VL3 & 63 & 66 & 66 & 67 & 67 & 63 & 77 & 68 & 59 & 63 & 66 & 1 \\
\hline
\end{tabular}




\section{Density and Basal Area}

A total of 7711 individuals were enumerated in 4.8 ha sampled area. The stem density of woody individuals ranged from 501 individuals per 0.4 ha in L2 to 743 in M3 (Table 2). There was no significant increase in the stand density $(\mathrm{r}=-0.06, \mathrm{p}=0.86)$ with the increase in patch size (Table 4). However, the density increased significantly with the increase in disturbance $(\mathrm{r}=0.71, \mathrm{p}=0.01)$. The dominant species across the fragments in terms of density includes Castanopsis purpurella, Helicia nilagirica, Persea odorratissima, Quercus semiserrata and Syzygium tetragonum (Annexure 1).

The basal area showed a gradual increase with increase in patch size $(\mathrm{r}=0.61, p=$ $0.01)$ but decreased with the increase in disturbance $(\mathrm{r}=-0.74, \mathrm{p}=0.01)$ (Table 4). The values were low (Table 2) in Medium (17.55 $\left.\pm 0.90 \mathrm{~m}^{2} / 0.4 \mathrm{ha}\right)$ and Small (18.35 \pm 0.91$)$ as compared to Large $(19.18 \pm 1.70)$ and Very large $(20.83 \pm 0.46)$ patches. In terms of basal area, the dominant species in different fragments sizes are Castanopsis purpurella, C. tribuloides, Helicia nilagirica, Quercus semiserrata and Syzygium tetragonum.

Table 4. Pearson's correlation between fragment size, disturbance and different phytosociological attributes

\begin{tabular}{|c|c|c|c|c|c|c|c|c|c|}
\hline Parameters & Area & \begin{tabular}{|c|}
$\begin{array}{c}\text { Disturbance } \\
\text { index }\end{array}$ \\
\end{tabular} & \begin{tabular}{|l|}
$\begin{array}{l}\text { Species } \\
\text { richness }\end{array}$ \\
\end{tabular} & Density & $\begin{array}{c}\text { Basal } \\
\text { area }\end{array}$ & $\mathbf{H}^{\prime}$ & D & $\mathbf{J}$ & \begin{tabular}{|c|}
$\begin{array}{c}\text { Cut } \\
\text { stumps }\end{array}$ \\
\end{tabular} \\
\hline Area & 1 & & & & & & & & \\
\hline $\begin{array}{l}\text { Disturbance } \\
\text { index }\end{array}$ & -0.51 & 1 & & & & & & & \\
\hline $\begin{array}{c}\text { Species } \\
\text { richness }\end{array}$ & 0.16 & -0.36 & 1 & & & & & & \\
\hline Density & -0.06 & $0.71 * *$ & -0.18 & 1 & & & & & \\
\hline Basal area & $0.61^{*}$ & $-0.74 * *$ & 0.19 & $-0.65^{*}$ & 1 & & & & \\
\hline $\mathbf{H}^{\prime}$ & 0.04 & -0.24 & $0.85^{* *}$ & 0.01 & -0.12 & 1 & & & \\
\hline D & -0.07 & 0.25 & $-0.67 *$ & -0.02 & 0.11 & $-0.95 * *$ & 1 & & \\
\hline $\mathbf{J}$ & -0.04 & -0.10 & $0.62 *$ & 0.15 & -0.31 & $0.94 * *$ & $-0.97 * *$ & 1 & \\
\hline Cut stumps & -0.43 & $0.67 *$ & -0.47 & 0.44 & -0.43 & -0.40 & 0.34 & -0.25 & 1 \\
\hline
\end{tabular}

* Significant at $\mathrm{p}<0.05$ and $* * \mathrm{p}<0.01$

\section{Population Structure}

The distribution of density in different diameter classes exhibits a reverse J-shaped curve. The number of individuals was concentrated in the lower diameter class $(5-15 \mathrm{~cm}$ $\mathrm{dbh}$ ) that gradually decline with the increase in diameter classes (Figure 4). The percentage contribution to total density by individuals in $5-15 \mathrm{~cm}$ diameter-class ranged from $55-74 \%$ while the density in upper diameter-classes $(>46 \mathrm{~cm})$ contributed to about $1.35-13 \%$. S1 contain the highest percentage $(74 \%)$ of individuals in the lower diameter-class $(5-15 \mathrm{~cm})$ followed by M3 (73\%), L1 (72), VL1 and VL2 (71 each), M1 (67), S2 and L3 (65 each), S3 (64), VL2 (62), M2 (56) and minimum was observed in L2 (55). VL3 had the highest number of individuals in the higher diameter class $(>66 \mathrm{~cm})$ with 12 stems per 0.4 ha. The stem density in the lowest diameter class $(5-$ 
$15 \mathrm{~cm}$ ) was highest in the sites corresponding to fragments with maximum disturbance score viz., M3 (542 individuals), L1 (510) and S1 (496). There was a total absence of individuals in $>66 \mathrm{~cm}$ dbh class in L2 (Figure 4).

Basal area distribution exhibited a very irregular trend among the different diameter classes and fragment sizes. The basal area was high in $16-25 \mathrm{~cm}$ diameter class in all the fragments that gradually decreased till $56-65 \mathrm{~cm}$ dbh class followed by an increase in > $66 \mathrm{~cm}$ dbh class in all the stands except in S2, M3 and L1 (Figure 4). The percentage contribution to the total basal area by the lower diameter class $(5-15 \mathrm{~cm})$ was highest in M3 (26\%) and lowest in VL1 and VL2 (12\% each). Similarly, the contribution to basal area by $>66 \mathrm{~cm}$ dbh class was highest in larger fragment classes i.e., VL3 (39\%), VL1 and VL2 (20\% each).
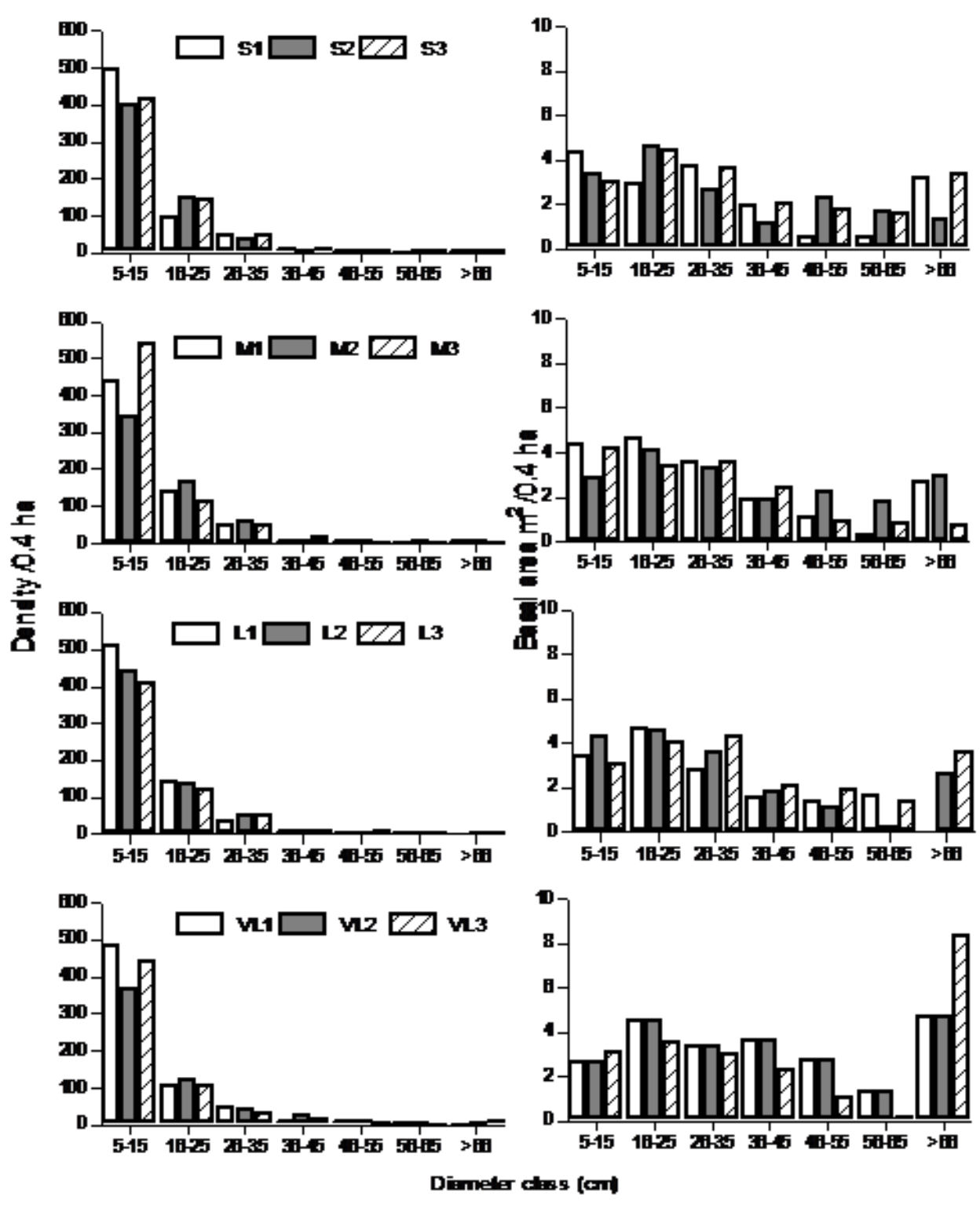

Figure 4. Distribution of density and basal area in different diameter classes in the studied fragments 


\section{Discussion}

The site characteristics of the studied fragments have shown that they are exposed to one or the other form of human disturbances. Forest fragmentation and anthropogenic disturbance can cause synergistic detrimental effect on the composition and structure of a plant community. The presence of 160 woody species belonging to 105 genera and 54 families indicates a considerable level of plant diversity in the study area. It seems that the variation in species richness among the fragments is due to land use history, geographical proximity to human habitation, and anthropogenic disturbances (Echeverria et al., 2007). The species richness showed no linear relation with the increase in patch size. This finding is similar to that reported from temperate forest of Chile (Echeverria et al., 2007) and tropical highlands of Chiapas, Mexico (Cayuela et al., 2006; Ochoa-Gaona et al., 2004). Such observation could be attributed to spatial shape complexity, dispersal mechanism, establishment and maintenance requirements of the species (Lord and Norton, 1990; Bierregaard et al., 1992). Isolation could be another important determinant of tree diversity in the fragments. The presence of patches close to each other might have favoured the recruitment of species. Protection and management may be one of the reasons for fair presence of species as observed in small fragments (S1 and S2). However, these small fragments are under severe threat due to illegal extraction and other human disturbances. Edge effect as well as human disturbance favoured pioneer species like Castanopsis purpurella, Helicia nilagirica, Quercus semiserrata, etc. Such species constituted 66-89\% of the total density and were dominant in all the fragments. Several studies have reported a preponderance of pioneer species after disturbance (Aguilar-Santaleiss and Castillo, 2013). The high similarity in species composition (52-77\%) among the studied fragments could be the close proximity of the patches to each other. Trees are long lived species and hence time lag may delay the impact of fragmentation on species composition shift among the fragments (Tabarelli et al., 2004).

The studied forests harbour a number of rare (Acer laevigatum, A. oblongum, Cinnamomum pauciflorum, Croton oblongus, Cyathea gigantea, Engelhardtia roxburghii, Litsea leata, Photonia integrifolia, Podocarpus neriifolia) and endemic species (Camellia cauduca, Citrus latipes, Ilex embeloides, I. venulosa, Schima khasiana, Viburnum simonsii) of the region. These remnants patches are also the natural habitat to many of the species threatened at global level (Eleocarpus prunifolius, Engelhardtia spicata, Ilex venulosa, Magnolia insignis, $M$. punduana). Therefore, these patches are important from conservation point of view (Appendix 1).

Shannon Wiener's diversity index showed no significant increase with area, but was negatively related to dominance index. High dominance of certain species in response to disturbances may be responsible for this behavioural pattern of the community. The negative relation of evenness and dominance index with area indicate a more diverse plant community especially in the smaller fragments. Such findings reveals the potential role of small fragments in conserving plant diversity in fragmented landscape (ToeldoAceves et al., 2014; Hernandez-Ruedas et al., 2014).

Though stem density showed no linear relationship with the fragment size, it increased significantly with disturbance. Increase in density with disturbance, reflects the resilience of the fragments following past disturbance. Recruitment of individuals in gaps created due to selective extraction may lead to an increase in stem density as observed in tropical forests of Kenya (Fashing et al., 2004) and India (Bhuyan et al., 2003). According to Atkinson and Marin-Spotta (2015), disturbed forests have high 
density and low basal area and are a characteristic feature of early successsional forest. Further, due to edge effect, there is a preponderance of fast growing pioneer species that often have high ecological amplitude to survive and compete for resources in fragmented patches (Laurance et al., 2004). The physical factors at the edge are known to restructure the plant community (Tomimatsu et al., 2015). An increase in the number of cut stumps and stem density and a decrease of basal area in the smaller fragment categories indicates that such patches are not only vulnerable to edge effect alone but also to anthropogenic encroachment.

The density- diameter distribution showed reverse J-shaped curve and indicates that the studied stands are regenerating. Majority of the individuals (60-70\%) were present in the lower diameter class $(5-15 \mathrm{~cm} \mathrm{dbh})$. The proportion of individuals in the lower diameter class $(5-15 \mathrm{~cm}$ dbh) was high in the disturbed sites. Recruitment of light tolerant species might have increased the stem density of the stand following disturbance (Majumdar et al., 2014). The low density in Very Large category may be due to thinning effect caused by larger trees as reported from the sholas of Western Ghats (Mohandass and Davidar, 2010). Extraction of trees for small timbers and poles were responsible for lower density in the middle diameter classes. Other causes could be the cultural disturbances in the form of selective felling during religious festivals and cremations (Jamir et al., 2006; Upadhaya et al., 2008).

There was a positive relation of basal area with patch size due to retention of some old growth large trees. Similar results have been reported from other subtropical forest of the region (Tripathi et al., 2010), tropical rainforest of Western Ghats (Bhat et al., 2000) and south eastern Madagascar (Ingram et al., 2005) and temperate forest of Southern Chile (Echeverria et al., 2007). Reduction of basal area in the smaller fragments represents a modification in the stand structure as the forest had returned to an earlier successional stage (Echeverria et al., 2007). Though the number of individuals was high in the lower diameter class $(5-15 \mathrm{~cm})$ but their contribution to basal area was low. The irregular distribution of basal area in different diameter classes could be attributed to selective extraction by the villagers.

\section{Conclusion}

The forest patches under study are of high conservation value due to its geographical location being in the Indo-Burma biodiversity hotspot (Mittermeier et al., 2004). The area houses a rich plant wealth and has been identified as a high priority area for conservation that lies outside protected area network in Meghalaya (Upadhaya et al., 2013). The study also highlights the potential role of small patches in conserving plant diversity of the region. Thus a network of patches could serve as habitat for subset populations of the original habitat that can interact and exchange resources. They may also act as corridor for various ecological interaction, serves as source of propagules for regeneration and aid in the successional process of the surrounding non forested matrix. Therefore, it may be suggested that human disturbances operating in the area needs to be reduced and the entire landscape be covered under the protected area network. We also suggest that other life forms such as shrubs, herbs, epiphytes should also be considered to understand the overall effect of fragmentation on plant diversity at landscape level. 
Acknowledgements. The authors are thankful to the Forest Department of Jaintia Hills Autonomous District Council for granting us necessary permission to work in the forest. The help and cooperation received from the local Raid Buam during the field survey is also acknowledged. The first author is thankful to UGC for financial support in the form of fellowship (Award No. F.15-6/December, 2011/2012 NET). The critical comments received from anyomous reviewers are acknowledged.

Conflict of Interest. We declare that there is no conflict of interest.

\section{REFERENCES}

[1] Aguilar-Santelises, R., del Castillo, R. F. (2013): Factors affecting woody plant species diversity of fragmented seasonally dry oak forests in the Mixteca Alta, Oaxaca, Mexico. - Revista Mexicana de Biodiversidad 84 (2): 575-590.

[2] Arroyo-Rodriguez, V., Pineda, E., Escobar, F., Benitez-Mendoza, J. (2008): Value of small patches in the conservation of plant-diversity in highly fragmented rainforest. Conservation Biology 23 (3): 729-739.

[3] Atkinson, E., Marin-Spiotta, E. (2015): Land use legacy effects on structure and composition of subtropical dry forests in St. Croix, U.S. Virgin Islands. - Forest Ecology and Management 335: 270-280.

[4] Benchimol, M., Peres, C. A. (2015): Edge-mediated compositional and functional decay of tree assemblages in Amazonian forest islands after 26 years of isolation. - Journal of Ecology 103: 408-420.

[5] Bhat, D. M., Naik, M. B., Patagar, S. G., Hedge, G. T., Kanade, Y. G., Hedge, G. N., Shastri, C. M., Shetti, D. M., Furtado, R. M. (2000): Forest dynamics in tropical rainforests of Uttara Kannada district in Western Ghats, India. - Current Science 79: 975985.

[6] Bhuyan, P., Khan, M. L., Tripathi, R. S. (2003): Tree diversity and population structure in undisturbed and human-impacted stand of tropical wet evergreen forest in Arunachal Pradesh, Eastern Himalayas, India. - Biodiversity and Conservation 12: 1753-1755.

[7] Bierregaard, R. O. Jr., Lovejoy, T. E., Kapos, V., dos Santos, A. A., Hutchings R. W. (1992): The biological dynamics of tropical rainforest fragments. - BioScience 42: 859866.

[8] Cayuela, L., Rey Benayas, J. M., Echeverria, C. (2006): Clearance and fragmentation of tropical montane forests in the Highlands of Chiapas, Mexico (1975-2000). - Forest Ecology and Management 226: 208-218.

[9] Central Groundwater Board (2013): Groundwater information booklet Jaintia Hills District, Meghalaya. - Technical Report Series: D, No. 49/2011-12.North Eastern Region, Guwahati.

[10] Champion, H.G., Seth, S. K. (1968): A revised survey of the forest types of India. Delhi, Manager of Publications.

[11] Chettri, A. (2010): Effect of Forest Fragmentation on Vascular Plant Diversty in Khangchendzonga Biosphere Reserve, Sikkim with Emphasis on Regeneration of Some Important Taxa. - PhD thesis, North-Eastern Hill University, Shillong.

[12] Echeverría, C., Newton, A.C., Lara, A., Benayas, J.M.R., Coomes, D.A., (2007): Impact of forest fragmentation in the temperate landscape of southern Chile. -Global Ecology and Biogeography. DOI: 10.1111/j.1466-8238.2007.00311 .x www. Blackwellpublishing.com/geb

[13] Fashing, P. J., Forrestel, A., Scully, C., Cords, M. (2004): Long term tree population dynamics and their implications for the conservation of the Kakamega forest, Kenya. Biodiversity and Conservation 13: 753-771.

[14] Gardner, T. A., Barlow, J., Chazdon, R. L., Harvey, C., Peres, C. A., Sodhi, N. S. (2009): Prospects for tropical forest biodiversity in a human modified world. - Ecology Letters 12: $561-582$. 
[15] Goedefroid, S., Koedam, N. (2003): How important are large vs. small fragments for the conservation of the woodland flora in an urban context? - Global Ecology and Biogeography 12: 287-298.

[16] Hernandez-Ruedas, M. A., Arroyo-Rodriguez, V., Meave, J. A., Martinez-Ramos, M., Ibarra-Manriquez, G., Martinez, E., Jamangape, G., Melo, F. P. L., Santos, B. A. (2014): Conserving tropical tree diversity and forest structure: the value of small rainforest patches in moderately-managed landscapes. - PLoS ONE http://dx.doi.org/10.1371/ journal.pone. 0098931.

[17] Hofmeister, J. K., Hosek, J., Brabec, M., Hedl, R., Modry, M. (2013): Strong influence of long-distance edge effect on herb-layer vegetation in forest fragments in an agricultural landscape. - Perspectives in Ecology, Evolution and Systematics 15: 293-303.

[18] Ingram, J. C., Dawson, T. P., Whittaker, R. J. (2005): Mapping tropical forest structure in southeastern Madagascar using remote sensing and artificial neutral networks. - Remote Sensing of Environment 94: 491-507.

[19] IUCN (2016): Standards and Petitions Subcommittee. 2016. Guidelines for Using the IUCN Red List Categories and Criteria. Version 12. Prepared by the Standards and Petitions Subcommittee in March 2010. Downloadable from http://intranet.iucn.org/ webfile /doc/SSC/RedList/RedList Guidelines.pdf.

[20] Jamir, S., Upadhaya, K., Pandey, H. N. (2006): Life form composition and stratification of montane humid forests in Meghalaya, northeast India. - Tropical Ecology 47 (2): 183190.

[21] Kolk, J., Naaf, T. (2015): Herb layer extinction debt in highly fragmented temperate forests-Completely paid after 160 years? - Biological Conservation 182: 164-172.

[22] Laurance, W. F., Delamonica, P., Laurance, S. G., Vasconcelos, H. L., Lovejoy, T. E. (2000): Rainforest fragmentation kills big trees. - Nature 404: 836.

[23] Laurance, W. F., Ferreira, L. V., Rankin-de Merona, J. M., Laurance, S. G. (1998): Rain forest fragmentation and the dynamics of Amazonian tree communities. - Ecology 79: 2032-2040

[24] Laurance, W. F., Lovejoy, T. E., Vasconcelos, H. L., Bruna, E. M., Didham, R. K., Stouffer, P. C., Gascon, C., Bierregaard, R. O., Laurance, S. G., and Sampaio, E. (2002): Ecosystem decay of Amazonian forest fragments: a 22-year investigation. - Conservation Biology 16: 605-618.

[25] Laurance, W., Oliveira, A. A., Laurance, S. G., Condit, R., Nascimento, H. E. M., Sanchez-Thorin, A. C., Lovejoy, T. E., Andrade, A. and D'Angelo, S. (2004): Pervasive alteration of tree communities in undisturbed Amazonian forests. - Nature 428: 171-175.

[26] Lindenmayer, D., Hobbs, R. J., Montague-Drake, R., Alexandra, J., Bennette, A., Burgman, M., Cale, P., Calhoun, A., Cramer, V., Cullen, P., Driscoll, D., Fahrig, L., Fischer, J., Franklin, J., Haila, Y., Hunter, M., Gibbons, P., Lake, S., Luck, G., MacGregor, C., Mclntyre, S., Nally, R. M., Manning, A., Miller, J., Mooney, H., Noss, R., Possingham, H., Saunders, D., Schmiegelow, F., Scott, M., Simberloff, D., Sisk, T., Tabor, G., Walker, B., Wiens, J., Woinarski, J., Zavaleta, E. (2008): A checklist for ecological management of landscapes for conservation. - Ecology Letters 11: 78-79.

[27] Lord, J. M., Norton, D. A. (1990): Scale and the spatial concept of fragmentation. Conservation Biology 4: 197-202.

[28] Mac-Arthur, R. H., Wilson, E. O. (1967): The Theory of Island Biogeography. Princeton University Press, Princeton, New Jersey.

[29] Magurran, A. E. (1998): Ecological Diversity and its Measurement. - Princeton University Press, Princeton.

[30] Majumdar, K., Shankar, U., Datta, B. K. (2014): Trends in tree diversity and stand structure during restoration: a case study in fragmented moist deciduous forest ecosystems of northeast India. - Journal of Ecosystems http://dx.doi.org/10.1155 /2014/845142. 
[31] Mikkelson, G. M. (1993): How do food webs fall apart? A study of changes in trophic structure during relaxation on habitat fragments. - Oikos 67: 539-547.

[32] Mir, A. H., Iralu, V., Pao, N. T., Chaudhury, G., Khonglah, C. G., Chaudhary, K. L., Tiwari B. K., Upadhaya, K. (2016): Magnolia lanuginosa (Wall.) Figlar \& Noot. in West Khasi Hills of Meghalaya, northeastern India: re-collection and implications for conservation. - Journal of Threatened Taxa 8: 8398-8402.

[33] Misra, R. (1968): Ecology Workbook. - Oxford-IBH Publishing Company, Calcutta.

[34] Mittermeier, R. A., Robles-Gil, P., Hoffmann, M., Pilgrim, J. D., Brooks, T. B., Mittermeier, C. G., Lamoreux, J. L., Fonseca, G. A. B. (2004): Hotspots Revisited: Earths Biologically Richest and Most Endangered Ecoregions. - CEMEX, Mexico City, Mexico, 390.

[35] Mohandass, D., Davidar, P. (2010): The relationship between area, and vegetation structure and diversity in montane forest (shola) patches in southern India. - Plant Ecology and Diversity 3(1): 67-76.

[36] Muller Dombois, D., Ellenberg, H. (1974): Aims and Methods of Vegetation Analysis. John Wiley and Sons, New York.

[37] Murcia, C. (1995): Edge effects in fragmented forests-implications for conservation. Trend in Ecology and Evolution 10: 58-62.

[38] Ochoa-Gaono, S., Gonzalez-Espinosa, M., Meave, J. A., Sorani-Dal Bon, V. (2004): Effect of fragmentation on the woody flora of the highlands of Chiapas, Mexico. Biodiversity and Conservation 13: 867-884.

[39] Orihuela, R. L. L., Peres, C. A., Mendes, G., Jarenkow, J. A., Taberelli, M. (2015): Markedly divergent tree assemblage responses to tropical forest loss and fragmentation across a strong seasonality gradient. - PLoS ONE 10 (8): e0136018. doi:10.1371/journal.pone. 0136018 .

[40] Page, N. V, Qureshi, Q., Rawat, G. S., Kushalappa, C. G. (2009): Plant diversity in sacred forest fragments of Western Ghats: a comparative study of four life forms. - Plant Ecology 206: 237-250.

[41] Pandey, H. N., Upadhaya, K., Jamir, A. S., Law, P. S., Tripathi, R. S. (2005): Floristic diversity in the sacred groves of Meghalaya. - In: Pandey, A. K., Wen, J. and Dogra, J. V. V. (eds.) Plant Taxonomy: Advances and Relevance. CBS Publishers and Distributors, New Delhi, 83-99.

[42] Pao, N. T., Upadhaya, K., Mir, A. H. (2016): Phenological behaviour of tree species in subtropical broadleaved humid forests of Jaintia Hills in Meghalaya, northeast India. International Research Journal of Bilogical Sciences 5 (7): 10-15.

[43] Santos, K., Kinoshita, L. S., Santos, F. A. M. (2007): Tree species composition and similarity in semi deciduous forest fragments of southern Brazil. - Biological Conservation 135: 268-277.

[44] Sarma, K. (2005): Impact of coal mining on vegetation: a case study in Jaintia Hills district of Meghalaya. - PhD thesis, International Institute for Geo-information science and Earth Observation Enschede, The Netherlands and Indian Institute of Remote Sensing, National Remote Sensing Agency (NRSA), Department of Space, Dehradun, India.

[45] Schoener, T. W. (2010): The MacArthur-Wilson equilibrium model. A chronicle of what it said and how it was tested. - In: Los, J. B. and Ricklefs R. E. (eds.) The Theory of Island Biogeography Revisited. Princeton University Press, Princeton, Oxford, UK, 5287.

[46] Sorensen, T. A. (1948): A method of establishing groups of equal amplitude in plant sociology based on similarity of species content, and its application to analyses of the vegetation on Danish commons. - K.dan Vidensk Selsk Biol Skr 5: 1-34.

[47] Tabarrelli, M., Silva, J. M. C., Gascon, C. (2004). Forest fragmentation, synergisms and the impoverishment of Neotropical forests. - Biodiversity and Conservation 13 (7): 14191425 . 
[48] Toledo-Aceves, T., Garcia-Franco, J. G., William-Linera, G., MacMillan, K., GallardoHernandez, C. (2014): Significance of remnant cloud forest fragments as reservoirs of tree and epiphytic bromeliad diversity. - Tropical Conservation Science 7 (2): 230-243.

[49] Tomimatsu, H., Suzuki, H. Y. S. N., Sato, C., Konuo, Y. (2015): Long-term dynamics of small fragmented inferred from patterns along agradient of fragment sizes. - Ecological Restoration 30: 1057-1064.

[50] Tripathi, O. P., Upadhaya, K., Tripathi, R. S., Pandey, H. N. (2010): Diversity, dominance and population structure of tree species along fragment-size gradient of a subtropical humid forest of northeast India. - Journal of Environmental and Earth Science 2 (2): 97-105.

[51] Turner, I. M. (1996): Species loss in fragments of tropical rain forest: a review of the evidence. - Journal of Applied Ecology 33: 200-209

[52] Upadhaya, K. (2015): Structure and floristic composition of subtropical broadleaved humid forest of Cherapunjee in Meghalaya northeast India. - Journal of Biodiversity Management and Forestry 4: 4. doi:10.4172/2327-4417.1000149.

[53] Upadhaya, K., Barik, S. K., Pandey, H. N., Tripathi, O. P. (2008): Response of woody species to anthropogenic disturbances in sacred forests of northeast India. - International Journal of Ecology and Environmental Sciences 34 (3): 245-257.

[54] Upadhaya, K., Choudhury, H., Odyuo, N. (2012): Floristic diversity of Northeast India and its conservation. - In: Mandal R.K. (ed.) International Environmental Economics: Biodiversity and Ecology. Discovery Publishing House Pvt. Ltd. New Delhi, 61-71.

[55] Upadhaya, K., Pandey, H.N., Law, P. S., Tripathi, R. S. (2003): Tree diversity in sacred groves of the Jaintia hills in Meghalaya, northeast India. - Biodiversity and Conservation 12: 583-597.

[56] Upadhaya, K., Thapa, N., Lakadong, N. J., Barik, S. K., Sarma, K. (2013): Priority areas of conservation in northeast India: A case study in Meghalaya based on plant specific diversity and endemism. - International Journal of Ecology and Environmental Sciences 39(2): 125-136.

[57] Vellend, M., Verheyen, K., Jacquemyn, H., Kolb, A., Calster, H. V., Peterken, G., Hermy, M. (2006): Extinction debt persists for more than a century following habitat fragmentation. - Ecology 87: 542-548.

[58] Zhu, H., Xu, Z. F., Wang, H., Li, B. G. (2004): Tropical rain forest fragmentation and its ecological and species diversity changes in southern Yunnan. - Biodiversity and Conservation 13: 1355-1372.

[59] Ziter, C., Bennett, E. M., Gonzalez, A. (2013): Function diversity and management mediate aboveground carbon stocks in small forest fragments. - Ecosphere 4 (7) Article 85: $1-21$. 


\section{APPENDIX}

Appendix 1. List of woody species and their density (per 0.4ha) in the studied fragments

\begin{tabular}{|c|c|c|c|c|c|c|c|c|c|c|c|c|c|}
\hline \multirow{3}{*}{ Species } & \multirow{3}{*}{ Family } & \multicolumn{12}{|c|}{ Fragment classes } \\
\hline & & \multicolumn{3}{|c|}{ Small } & \multicolumn{3}{|c|}{ Medium } & \multicolumn{3}{|c|}{ Large } & \multicolumn{3}{|c|}{ Very Large } \\
\hline & & S1 & S2 & S3 & M1 & M2 & M3 & L1 & L2 & $\mathbf{L 3}$ & VL1 & VL2 & VL3 \\
\hline *Acer laevigatum Wall. & Aceraceae & 9 & 4 & 1 & 2 & 3 & & 3 & 1 & 1 & 3 & 1 & 5 \\
\hline *Acer oblongum Wall. & Aceraceae & - & - & - & - & - & - & - & 2 & 3 & - & - & - \\
\hline Acronychia pedunculata (L.) Miq. & Rutaceae & - & 1 & - & 9 & 8 & 2 & 14 & 11 & 7 & 1 & 2 & 9 \\
\hline Adinandra sp. & Theaceae & - & - & - & 1 & - & - & - & - & 2 & 2 & 1 & 1 \\
\hline *^Agapetes variegata (Roxb.) D. Don. & Myrsinaceae & - & - & - & 3 & - & - & 1 & - & - & - & - & - \\
\hline Albizia chinensis (Osb.) Merr. & Euphorbiaceae & 1 & - & - & - & - & - & - & - & - & - & - & - \\
\hline Alyxia fascicularis Benth. & Apocyanaceae & - & - & - & 1 & - & - & - & - & - & - & - & - \\
\hline Antidesma khasianum Hk.f. & Euphorbiaceae & - & - & - & - & - & - & - & - & 1 & 1 & - & 1 \\
\hline${ }^{\wedge}$ Ardisia griffithii $\mathrm{Cl}$. & Myrsinaceae & - & 2 & 1 & - & 3 & - & 1 & 1 & - & - & - & 1 \\
\hline Ardisia virens Kurz & Myrsinaceae & 3 & - & - & - & - & - & - & - & - & - & - & - \\
\hline *^Beilshmiedia assamica Meissn. & Lauraceae & 3 & 1 & 4 & & 3 & 6 & 3 & 1 & 1 & 3 & - & 1 \\
\hline Betula alnoides Buch.-Ham. ex D.Don & Betulaceae & - & - & - & 4 & - & - & - & - & - & 1 & - & - \\
\hline Casearia glomerata Roxb. & Flacoutiaceae & 2 & & 4 & 1 & 1 & - & - & 6 & 4 & 2 & 1 & \\
\hline Callophyllum polyanthum Choisy & Clusiaceae & 10 & - & - & 1 & & 6 & 2 & 2 & & 23 & & 2 \\
\hline${ }^{\wedge}$ Camellia cauduca Cl.ex Brandis & Theaceae & 4 & 9 & 4 & 16 & 39 & 14 & 11 & 18 & 21 & 5 & 12 & 22 \\
\hline Camellia caudata Wall. & Theaceae & 5 & 8 & 1 & 2 & 15 & - & 7 & - & 5 & 1 & 2 & 12 \\
\hline Capparis assamica Hk.f. \& Th. & Capparaceae & - & 9 & 2 & & - & - & 1 & - & 1 & - & - & - \\
\hline Castanopsis armata Spach. & Fagaceae & 13 & 16 & 3 & 21 & & 8 & 11 & 7 & 8 & 30 & 29 & 13 \\
\hline Castanopsis kurzii (Hance) Biswas & Fagaceae & 17 & 20 & 7 & 25 & 11 & 2 & 11 & 3 & 9 & 19 & 22 & 27 \\
\hline
\end{tabular}

APPLIED ECOLOGY AND ENVIRONMENTAL RESEARCH 15(4):385-407.

http://www.aloki.hu • ISSN 15891623 (Print) • ISSN 17850037 (Online)

DOI: http://dx.doi.org/10.15666/aeer/1504_385407

๑ 2017, ALÖKI Kft., Budapest, Hungary 


\begin{tabular}{|c|c|c|c|c|c|c|c|c|c|c|c|c|c|}
\hline Castanopsis purpurella (Miq.) Balak. & Fagaceae & 49 & 42 & 12 & 25 & 25 & 20 & 5 & 19 & 52 & 42 & 33 & 37 \\
\hline Castanopsis tribuloides (Sm.) DC & Fagaceae & 30 & 29 & 30 & 21 & 51 & 16 & 20 & 9 & 7 & 28 & 52 & 37 \\
\hline Cinnamoтит bejolghota (Buch.-Ham.) Sweet. & Lauraceae & - & - & - & - & - & 1 & 1 & - & 1 & 1 & - & - \\
\hline *Cinnaтотит pauciflorum Nees & Lauraceae & - & - & - & - & - & - & - & - & - & 1 & 2 & - \\
\hline Cinnaтотит tamala Fr. Nees & Lauraceae & 20 & 5 & 2 & 17 & 3 & 17 & 14 & 10 & 5 & 14 & 4 & 25 \\
\hline Cinnamomum zeylanicum Blume & Lauraceae & 10 & 1 & 1 & - & 1 & 2 & 1 & 6 & 2 & 1 & 1 & 9 \\
\hline${ }^{\wedge}$ Citrus latipes (Swingle) Tanaka & Rutaceae & - & - & - & 2 & - & - & - & - & - & - & - & - \\
\hline Clerodendrum bracteatum Wall.ex Walp. & Verbenaceae & - & - & - & - & - & 2 & - & - & - & - & - & - \\
\hline Clerodendrum colebrookianum Walp. & Verbenaceae & 1 & - & - & - & - & - & - & - & 1 & 1 & 1 & - \\
\hline Clerodendrum wallichii Merr. & Verbenaceae & & - & - & - & - & - & - & 1 & - & - & - & - \\
\hline${ }^{\wedge}$ Coffea khasiana Hk.f. & Rubiaceae & - & - & - & - & - & - & - & - & - & 1 & & 1 \\
\hline *Croton oblongus Burm.f. & Euphorbiaceae & 3 & - & - & 3 & 5 & - & - & 1 & 1 & 4 & & 1 \\
\hline *Cyathea gigantea (Wall.ex Hook.) Holtt. & Cyatheaceae & 1 & - & 1 & 4 & - & 5 & - & - & - & - & - & - \\
\hline Daphne involucrate Wall. & Thymelaeaceae & - & 3 & - & 1 & - & - & - & 2 & - & - & 1 & 4 \\
\hline *Daphniphyllum himalayense (Benth.) Mull. Arg. & Daphniphyllaceae & 1 & - & - & 1 & - & - & - & 2 & 3 & 3 & 1 & 2 \\
\hline Decaspermum paniculatum (L.)Kurz. & Myrtaceae & - & - & 3 & 3 & 1 & 5 & - & - & 2 & - & - & - \\
\hline Diospyros kaki Thunb. & Ebenaceae & 1 & - & 1 & 2 & - & 3 & 5 & 1 & 3 & - & - & - \\
\hline Dysoxylon gobara (Buch.-Ham.) Merr. & Meliaceae & - & - & - & - & 1 & - & - & - & - & - & 3 & - \\
\hline Elaeagnus latifolia $\mathrm{Hk} . \mathrm{f}$. & Elaeagnaceae & - & - & 2 & - & - & - & - & - & - & - & 1 & - \\
\hline Elaeocarpus lanceifolius Roxb. & Elaeocarpaceae & 2 & 1 & 2 & & 7 & 3 & & 3 & - & - & - & 5 \\
\hline \#Elaeocarpus prunifolius Wall.ex Mull.Berol. & Elaeocarpaceae & 29 & 27 & 3 & 15 & 5 & 13 & 4 & 13 & 4 & 10 & 6 & 2 \\
\hline Embelia ribes Burm.f. & Myrsinaceae & - & - & - & - & 1 & - & 1 & 1 & - & - & - & - \\
\hline *Engelhardtia roxburghiana Wall. & Juglandaceae & - & - & - & 1 & 8 & - & 3 & & 3 & - & - & 1 \\
\hline \#Engelhardtia spicata Lechen ex Bl. & Juglandaceae & 1 & 4 & 10 & - & 3 & - & 7 & 2 & & 12 & 1 & 3 \\
\hline Eriobotryo bengalensis Hk.f. & Rosaceae & 6 & - & - & 2 & - & - & - & - & - & - & - & - \\
\hline
\end{tabular}

APPLIED ECOLOGY AND ENVIRONMENTAL RESEARCH 15(4):385-407.

http://www.aloki.hu • ISSN 15891623 (Print) • ISSN 17850037 (Online)

DOI: http://dx.doi.org/10.15666/aeer/1504_385407

(c) 2017, ALÖKI Kft., Budapest, Hungary 


\begin{tabular}{|c|c|c|c|c|c|c|c|c|c|c|c|c|c|}
\hline *^Erythroxylon kunthianum Wall. ex Kurz & Erythroxylaceae & 4 & 7 & 8 & 5 & 1 & 2 & 16 & 4 & 10 & 13 & & 2 \\
\hline Euonymus attenиatus Laws. & Celastraceae & - & - & 1 & - & - & - & 2 & 2 & - & 1 & - & - \\
\hline *Euonymus bullatus Wall. ex Laws & Celastraceae & - & - & - & 1 & 1 & 1 & - & - & - & - & - & - \\
\hline Euоnymus theifolius Wall. ex Laws & Celastraceae & 1 & - & - & - & - & 1 & 1 & - & 1 & - & - & - \\
\hline Eurya accuminata DC. & Theaceae & - & - & - & - & - & - & - & 1 & 2 & - & 3 & 3 \\
\hline Eurya japonica Thunb. & Theaceae & 5 & 13 & 53 & 25 & 15 & 15 & 22 & 1 & 9 & 11 & 7 & 26 \\
\hline Exbucklandia populnea (R.Br. ex Griff.) & Hamamelidaceae & 1 & - & - & 5 & 1 & - & - & 3 & - & 6 & 8 & 11 \\
\hline Ficus hirta Vahl & Moraceae & - & 1 & - & - & - & - & - & 1 & - & 1 & - & - \\
\hline Ficus nerifolia $\mathrm{Sm}$. & Moraceae & - & 7 & - & - & 2 & - & 1 & 1 & - & - & - & 1 \\
\hline *^Fraxinus floribunda Wall. & Oleaceae & 1 & 1 & 1 & - & - & 1 & 5 & 8 & 1 & 2 & 1 & - \\
\hline Garcinia anomala Planch. \& Triana & Clusiaceae & 2 & - & - & - & - & 1 & & 1 & - & 9 & - & 13 \\
\hline Garcinia cowa Roxb. ex DC. & Clusiaceae & 30 & 10 & 1 & 2 & - & - & 3 & 2 & 4 & 7 & - & 3 \\
\hline Garcinia morella Desr. & Clusiaceae & - & - & 1 & - & 5 & - & 2 & - & - & - & 1 & - \\
\hline${ }^{\wedge}$ Glochidion thomsonii Hk.f. & Euphorbiaceae & 12 & 7 & 1 & 1 & 4 & 7 & - & 7 & 6 & 14 & 2 & 8 \\
\hline Glycosmis cymosa (Kurz) Narayan & Rutaceae & 1 & 13 & 2 & 31 & 51 & 7 & 11 & 29 & 19 & - & 1 & - \\
\hline Helicia nilagirica Bedd. & Proteaceae & 43 & 36 & 44 & 23 & 29 & 82 & 66 & 13 & 70 & 29 & 99 & 36 \\
\hline Heteropanax fragrans (D.Don.) Seem. & Araliaceae & - & - & - & - & - & - & - & - & 2 & 3 & - & - \\
\hline Hiptage bengalensis (L.) Kurz & Malphigiaceae & 3 & - & - & - & - & - & - & - & 1 & - & - & - \\
\hline Hyptianthera stricta (Wild.) Wt. \& Arn. & Rubiaceae & - & 1 & - & 1 & - & - & - & - & - & - & - & - \\
\hline *^Ilex embeloides Hk.f. & Aquifoliaceae & 10 & 7 & 3 & 3 & 4 & 1 & 1 & 1 & 1 & 6 & 2 & 2 \\
\hline ^Ilex excelsa (Wall.) Hk.f. & Aquifoliaceae & 1 & & 3 & 5 & 7 & - & 6 & - & - & 2 & 2 & 2 \\
\hline Ilex odorata Buch.-Ham ex D.Don & Aquifoliaceae & 25 & 19 & 5 & 3 & 5 & 1 & 2 & 1 & 3 & 2 & 2 & 3 \\
\hline Ilex sp. & Aquifoliaceae & - & - & 1 & - & - & - & - & - & - & - & 2 & - \\
\hline *^\#Ilex venulosa Hk.f. & Aquifoliaceae & 11 & - & 3 & 26 & 4 & 7 & 16 & 5 & - & 4 & 1 & 2 \\
\hline Itea macrophylla Wall. & Iteaceae & - & 1 & - & 1 & 1 & - & 1 & - & - & - & - & - \\
\hline
\end{tabular}

APPLIED ECOLOGY AND ENVIRONMENTAL RESEARCH 15(4):385-407.

http://www.aloki.hu • ISSN 15891623 (Print) • ISSN 17850037 (Online)

DOI: http://dx.doi.org/10.15666/aeer/1504_385407

(c) 2017, ALÖKI Kft., Budapest, Hungary 


\begin{tabular}{|c|c|c|c|c|c|c|c|c|c|c|c|c|c|}
\hline Itea chinensis Hk. f. & Iteaceae & 3 & - & - & - & - & - & - & - & - & - & 2 & - \\
\hline Ixonanthes sp. & Ixonanthaceae & - & 2 & - & - & - & - & - & - & - & 1 & - & - \\
\hline Ixora nigricans Wt. \& Arn. Pradr. & Rubiaceae & - & - & - & - & - & - & - & - & - & - & - & 4 \\
\hline ^Ixora subsessilis G.Don & Rubiaceae & - & - & - & - & - & - & 1 & - & - & - & - & 1 \\
\hline Lasianthus lucidus Blume & Rubiaceae & - & - & - & - & 1 & - & - & - & - & - & - & - \\
\hline Lasianthus sp. & Rubiaceae & - & - & - & - & - & - & - & 2 & - & - & - & - \\
\hline *Lasianthus tubiferus Hk.f. & Rubiaceae & 3 & - & - & - & 2 & 1 & - & - & - & - & - & - \\
\hline Leea indica (Burm.) Merr. & Leeaceae & 2 & - & - & 3 & 3 & - & - & - & - & 3 & - & - \\
\hline Ligustrum compactum Hk.f \& Th. ex Brandis & Oleaceae & - & - & 1 & 2 & 1 & - & - & - & - & - & - & - \\
\hline Ligustrum robustum (Roxb.) Blume & Oleaceae & - & 2 & 17 & 4 & 13 & - & 7 & 4 & 2 & 3 & & 2 \\
\hline$* \wedge$ Lindera latifolia Hk.f. & Lauraceae & 1 & - & - & - & - & - & - & - & - & - & 2 & - \\
\hline Lithocarpus dealbatus (Hk.f. \& Th. ex Miq.) Rehder. & Fagaceae & - & - & 5 & 12 & 6 & - & 1 & 4 & - & - & - & - \\
\hline Lithocarpus elegans (B1.) Hatus. ex Soep. & Fagaceae & 15 & 4 & 7 & 10 & 19 & 12 & 20 & 3 & 3 & - & 20 & 4 \\
\hline Lithocarpus fenestratus (Roxb.) Rehder. & Fagaceae & 4 & - & - & - & - & 53 & - & 33 & 15 & 12 & 1 & - \\
\hline${ }^{* \wedge}$ Litsea elongata (Nees) Hk.f. & Fagaceae & 26 & 1 & - & - & - & - & 2 & 1 & 1 & 4 & 3 & 2 \\
\hline$* \wedge$ Litsea laeta Wall.ex Nees & Fagaceae & - & - & 11 & 2 & - & 12 & - & 4 & 3 & 16 & - & 1 \\
\hline Litsea salicifolia (Roxb.ex.Nees) Hk.f. & Fagaceae & - & 6 & 3 & 5 & - & 5 & 6 & - & 5 & - & 9 & 21 \\
\hline Macaranga denticulata Muell.- Arg. & Euphorbiaceae & - & - & - & - & - & - & - & - & 2 & - & - & - \\
\hline Maesa indica (Roxb.) Wall. & Myrsinaceae & - & - & 1 & - & 1 & - & - & - & - & - & - & - \\
\hline Mahonia pycnophylla (Fedde) Takeda & Berberidaceae & 1 & 5 & & 1 & & 1 & 3 & 1 & - & - & - & - \\
\hline \#*Magnolia insignis (Wall.) Bl. & Magnoliaceae & - & 3 & 4 & 10 & 2 & 4 & 1 & 3 & - & 6 & & 3 \\
\hline Magnolia sp. & Magnoliaceae & - & - & - & 2 & - & - & - & - & - & - & - & - \\
\hline \#*Magnolia punduana Hk.f. \& Th. & Magnoliaceae & - & - & 1 & 18 & 4 & 5 & 3 & 5 & - & 4 & - & 11 \\
\hline Microtropis discolor (Wall.) Arn. & Celastraceae & 1 & - & - & 1 & - & - & - & 2 & - & - & - & - \\
\hline Miliusa roxburghiana (Wall.) Hk.f. \& Th. Th. & Annonaceae & - & - & - & - & - & - & - & - & - & 4 & - & - \\
\hline
\end{tabular}

APPLIED ECOLOGY AND ENVIRONMENTAL RESEARCH 15(4):385-407. http://www.aloki.hu • ISSN 15891623 (Print) $\bullet$ ISSN 17850037 (Online)

DOI: http://dx.doi.org/10.15666/aeer/1504_385407

(c) 2017, ALÖKI Kft., Budapest, Hungary 


\begin{tabular}{|c|c|c|c|c|c|c|c|c|c|c|c|c|c|}
\hline Millettia pulchra (Benth.) Kurz. & Fabaceae & - & - & 1 & 1 & 1 & - & - & - & - & - & - & - \\
\hline Morinda angustifolia Roxb. & Rubiaceae & - & 1 & 1 & - & - & - & 2 & - & - & - & - & 2 \\
\hline Мисипа sp. & Fabaceae & - & - & - & 3 & - & - & - & - & - & - & - & - \\
\hline Mussaenda roxburghii Hk.f. & Rubiaceae & - & - & - & - & 1 & - & - & - & - & - & - & - \\
\hline Meyna laxiflora Robyns. & Rubiaceae & - & - & 2 & - & - & 2 & 2 & - & 1 & - & - & - \\
\hline Myrica esculenta Buch.-Ham. ex D.Don & Myricaceae & 10 & 10 & 13 & 24 & 20 & 18 & 4 & 12 & 13 & 31 & 49 & 14 \\
\hline Myrsine capitellata (Wall.) Mez. & Myrsinaceae & - & - & - & - & - & 3 & 2 & - & - & - & - & - \\
\hline Myrsine semiserrata Wall. & Myrsinaceae & 4 & 3 & 1 & 8 & 2 & 1 & 3 & 1 & - & 3 & 6 & 1 \\
\hline Neolitsea umbrosa (Nees.) Gamble & Lauraceae & 8 & 4 & 2 & 1 & 4 & - & 1 & - & - & - & 10 & 4 \\
\hline Neolitsia cassia (L.) Koster. & Lauraceae & - & 3 & - & - & - & 4 & 14 & 2 & 2 & 17 & - & 1 \\
\hline Olea dentata Wall.ex DC. & Oleaceae & - & - & - & - & 2 & - & - & - & - & 2 & - & - \\
\hline Persea duthiei (King ex Hk.f.) Koster. & Lauraceae & - & - & - & - & - & - & - & - & 3 & 2 & 57 & 2 \\
\hline Persea odorratissima (Nees) Koster. & Lauraceae & 2 & 3 & 18 & 31 & 23 & 30 & 20 & 5 & 16 & 11 & 8 & 47 \\
\hline Phoebe lanceolata (Nees) Nees & Lauraceae & - & - & 3 & 3 & 3 & 2 & 2 & - & - & 9 & 6 & 7 \\
\hline *^Photinia arguta Lindl. & Rosaceae & - & - & 1 & - & - & - & - & - & - & - & - & - \\
\hline *^Photinia cuspidata (Bertol.) Balak. & Rosaceae & - & - & - & - & - & - & 1 & - & - & - & 3 & - \\
\hline *^Photinia integrifolia Lindl. & Rosaceae & - & - & - & 6 & 2 & - & - & 1 & - & 1 & 1 & 1 \\
\hline Photinia notoniana Wt. \& Arn. & Rosaceae & - & - & - & 5 & 3 & - & 2 & 1 & 2 & 4 & 1 & - \\
\hline Pinus kesiya Royle ex. Gordon & Pinaceae & - & - & - & - & - & 3 & - & - & - & - & 7 & 3 \\
\hline Pithocellobium monodelphum (Roxb.) Koster. & Fabaceae & 1 & 1 & - & - & 1 & 2 & 1 & 1 & 1 & 2 & 1 & 3 \\
\hline Pittosporum humile Hk.f. \& Th. & Pittosporaceae & 2 & 13 & 20 & 12 & 28 & 49 & 21 & 27 & 25 & 20 & 10 & 14 \\
\hline ^Podocarpus neriifolia D.Don & Podocarpaceae & - & - & - & 1 & - & - & - & - & - & - & - & - \\
\hline Prunus punctata Hk. f. \& Th. & Rosaceae & 2 & 1 & 3 & 3 & 2 & 10 & 2 & 1 & 2 & 3 & 4 & - \\
\hline Psychotria adenophylla Wall. & Rubiaceae & - & 3 & & 1 & 4 & - & 2 & 4 & - & 1 & - & - \\
\hline *^Psychotria simplocifolia Kurz. & Rubiaceae & 3 & - & 9 & 3 & 2 & - & - & - & - & - & 2 & 1 \\
\hline
\end{tabular}

APPLIED ECOLOGY AND ENVIRONMENTAL RESEARCH 15(4):385-407.

http://www.aloki.hu • ISSN 15891623 (Print) $\bullet$ ISSN 17850037 (Online)

DOI: http://dx.doi.org/10.15666/aeer/1504_385407

(c) 2017, ALÖKI Kft., Budapest, Hungary 


\begin{tabular}{|c|c|c|c|c|c|c|c|c|c|c|c|c|c|}
\hline Pyrularia edulis DC. & Santalaceae & 1 & - & - & - & - & - & - & - & - & 1 & - & - \\
\hline Pyrus pashia D.Don & Rosaceae & 1 & - & - & - & - & - & - & - & - & - & - & - \\
\hline Quercus sp. & Fagaceae & 30 & - & - & - & 1 & 36 & - & 10 & 20 & - & 1 & 3 \\
\hline *Quercus glauca Thunb. & Fagaceae & 13 & - & 3 & - & - & - & 1 & - & 2 & 7 & 1 & - \\
\hline Quercus kamroopii D.Don & Fagaceae & 9 & - & - & - & 1 & 8 & - & 3 & 2 & 3 & 4 & - \\
\hline Quercus lancifolius Roxb. & Fagaceae & 13 & - & - & - & 1 & - & - & 1 & - & - & 1 & - \\
\hline Quercus semiserrata Roxb. & Fagaceae & 23 & 74 & 89 & 7 & 21 & 71 & 139 & 7 & 109 & 16 & 5 & 13 \\
\hline Randia spinosa (Thunb.) Poir. & Rutaceae & & - & - & - & - & - & - & - & - & 2 & - & - \\
\hline Randia wallichii Hk.f. & Rutaceae & 3 & - & - & - & - & - & 1 & 1 & 1 & - & - & - \\
\hline Rauvolfia densiflora (Wall.) Benth. ex Hk.f. & Apocyanaceae & & - & - & - & - & - & - & - & - & - & - & 1 \\
\hline Rhus accuminata DC. & Anacardaceae & 17 & 7 & 15 & 10 & 10 & 26 & 32 & 22 & 8 & 23 & 2 & 2 \\
\hline Sarcococca saligna (D.Don.) Muell.-Arg. & Anacardaceae & - & - & - & - & - & - & - & - & - & 2 & - & 2 \\
\hline$* \wedge$ Sarcosperma griffithii $\mathrm{Cl}$. & Sapotaceae & 23 & 3 & 12 & 46 & 14 & 7 & 22 & 14 & 8 & 11 & 3 & 11 \\
\hline Schefflera glomerulata $\mathrm{Li}$. & Araliaceae & 4 & - & - & - & - & - & - & 1 & - & - & - & - \\
\hline Schefflera hypoleuca (Kurz) Harms & Araliaceae & 1 & 6 & 5 & 15 & 7 & 3 & - & 15 & 1 & 12 & - & 3 \\
\hline Schefflera venulosa (Wt. \&Arn.) Harms & Araliaceae & 6 & 2 & - & - & 1 & - & 12 & 3 & - & 7 & - & - \\
\hline 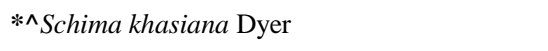 & Theaceae & - & 2 & 1 & 1 & 2 & - & - & - & - & 6 & 2 & 6 \\
\hline Schima wallichii (DC.) Korth. & Theaceae & 5 & 48 & 3 & 11 & 6 & 13 & 22 & 54 & 8 & 36 & 15 & 21 \\
\hline Skimmia laureola (DC.) Sieb \& Zucc.ex Walp. & Rutaceae & - & 1 & - & - & - & - & 2 & - & - & - & - & - \\
\hline Sterculia roxburghii Wall. & Sterculiaceae & - & 5 & 9 & - & 4 & 2 & 14 & 4 & 2 & 1 & - & - \\
\hline Styrax serrulatum Roxb. & Styracaceae & 3 & 14 & 12 & 9 & - & 9 & 11 & 4 & 16 & 1 & - & - \\
\hline Symplocos glomerulata King ex Cl. & Symplocaceae & 3 & - & 7 & - & - & - & - & 1 & - & - & - & 1 \\
\hline Symplocos javanica (Bl.) Kurz. & Symplocaceae & 4 & - & 1 & 1 & 2 & 28 & 2 & 3 & 3 & 3 & 2 & 10 \\
\hline Symplocos paniculata (Thunb.)Miq. & Symplocaceae & - & - & - & 1 & - & 1 & - & - & - & - & - & - \\
\hline Symplocos spicata Roxb. & Symplocaceae & 16 & 8 & 22 & 10 & 28 & 4 & 23 & 7 & 7 & 13 & 25 & 18 \\
\hline
\end{tabular}

APPLIED ECOLOGY AND ENVIRONMENTAL RESEARCH 15(4):385-407.

http://www.aloki.hu • ISSN 15891623 (Print) $\bullet$ ISSN 17850037 (Online)

DOI: http://dx.doi.org/10.15666/aeer/1504_385407

(๖) 2017, ALÖKI Kft., Budapest, Hungary 


\begin{tabular}{|c|c|c|c|c|c|c|c|c|c|c|c|c|c|}
\hline Syzygium cumini (L.) Skeels & Myrtaceae & - & 29 & 34 & & 11 & - & - & - & - & 1 & 4 & 10 \\
\hline Syzygium macrocarpum (Roxb.) Balak. & Myrtaceae & 25 & - & - & 2 & 1 & 32 & - & 5 & 35 & 16 & - & - \\
\hline Syzygium tetragonum Kurz. & Myrtaceae & - & 48 & 68 & 49 & 18 & 16 & 15 & 6 & 26 & 41 & 20 & 27 \\
\hline *Tupidanthus calyptratus Hk. f. \& Th. & Araliaceae & - & - & - & - & - & - & - & - & 1 & - & - & - \\
\hline ^Turpinia nepalensis Wall. ex Wt.\&Arn. & Styphyleaceae & - & - & - & 1 & - & - & - & - & - & - & - & - \\
\hline Uncaria sp. & & - & - & - & - & - & - & - & - & - & - & 1 & - \\
\hline Vaccinium sprengelii (G.Don) Rehd. & Ericaceae & - & - & 1 & 3 & 5 & 1 & & 1 & & 2 & & 4 \\
\hline Vernonia volkameriifolia DC. & Asteraceae & 2 & 3 & & 3 & 3 & 1 & 1 & & 1 & - & - & 4 \\
\hline Viburnum coriaceum $\mathrm{Bl}$. & Caprifoliaceae & 6 & - & - & - & - & - & - & 1 & 3 & - & 1 & - \\
\hline Viburnum odorratissamum Ker. & Caprifoliaceae & - & - & - & - & - & - & - & 2 & - & 3 & - & - \\
\hline${ }^{\wedge}$ Viburnum simonsii Hk.f. \& Th. & Caprifoliaceae & - & - & 19 & 2 & & 12 & - & 1 & - & - & - & - \\
\hline Wendlandia wallichii Wt. \& Arn. & Rubiaceae & 3 & - & 2 & 3 & 1 & 4 & 12 & 16 & 3 & 5 & 1 & 7 \\
\hline Zanthoxylum armatum DC. & Rutaceae & - & - & - & 2 & 1 & - & - & - & - & - & - & - \\
\hline Unidentified sp 1 & Apocyanaceae & - & - & - & - & - & - & - & - & - & - & - & 1 \\
\hline Unidentified $s p 2$ & Anacardaceae & - & - & - & - & - & 1 & - & - & - & - & - & - \\
\hline
\end{tabular}

‘'’ = Indicates absences; ‘*’ = Rare; ‘^’= Endemic; '\#’ = Threatened 